\title{
Understanding Christian Conversion as a Post-Relational Ontological (Re)turn to Relations
}

\author{
Jill Hurley
}

\begin{abstract}
Since 1950, when Nepal opened its doors to Christianity, people have been converting in rapid pace. Anthropologists have theorized for decades that in the process of converting from any religion to Christianity, persons experience a relational rupture. By combining the set theory of Hiebert and postrelational ontological turn theory of Holbraad and Pedersen, I explore how the anthropological approach must change its starting point in order to understand how and why conversion happens. As we understand the motivations for conversion, we can see that relational rupture does not exist for Christian converts because of the core emphasis on relationality found within Christianity. Through ethnographic research, I was able to effectively show how conversion to Christianity should be considered a post-relational ontological re(turn) to relations.
\end{abstract}

Kathmandu is home to two of the world's leading religions: Hinduism and Buddhism, yet there are large populations of Muslims and Christians that are thriving there as well. The polytheistic nature of Nepal is obvious the moment you set foot on the soil, as every car and bus is decorated with a different religious icon. With a population of one million people, Kathmandu is crowded and bustling with the busyness of life. The lack of infrastructure and the poverty rate are obvious and have been exacerbated since a 7.8 magnitude earthquake hit Nepal in 2015. The country is still undergoing a rebuilding process, which is evident in the piles of bricks, timber, or other building supplies that litter the roads every few hundred feet. In addition to those obstacles, since they are considered holy in the Hindu faith, cows wander around freely, sleeping on sidewalks and many times congregating in the middle of the sometimes unpaved roads. Between the dirt roads, the surrounding mountains trapping in smog, the cows and other stray animals using public roadways as their own personal lavatory, the odor and dust can be unbearable. Even native Nepalis wear dust masks as they walk around the city each day. But once you leave Kathmandu and travel to the villages, the smog and pollution are virtually non-existent because of the rise in altitude and the agricultural lifestyle, though the earthquake damage and poverty are still evident.

Nepal is home to the fastest growing population of Christians worldwide according to the Center for the Study of Global Christianity at Gordon-Conwell Theological Seminary (2013:38). I traveled to Nepal in the summer of 2017 in order to gain a deeper understanding of the transformative nature of conversion. I was able to spend nine weeks working primarily in the villages of Palung and Kunchal, connecting with the leadership from a network of village churches. Through participant observation, formal interviews and focus groups, I was able to begin to understand the conversion process along with how relationships are transformed by it.

For the research, I found myself traveling between Kathmandu, Palung and Kunchal on a weekly basis. In each location, I spent time talking with people about their journey of conversion to Christianity, primarily from Hinduism. While there is much to learn about people as they go through a conversion process, I was most interested in the transformative nature of conversion. I began to question whether conversion happens in a singular moment or if it is rather a sequence of moments that culminate in an ontological shift. The way anthropologists define the process of conversion can have significant implications on the rest of our research, so we must establish a plumb line.

By examining multiple conversion narratives, I will describe how the anthropological approach to studying conversion must begin with Hiebert's centered-set theory in order to analyze the full journey. Then, in order to understand its impact on social relations, I will look at the "post-relational ontological turn" theory described by Holbraad and Pedersen. I propose, that "post-relational ontological turn" theory does not fully capture the transformative process of conversion. As 
the authors acknowledge, describing conversion to Christianity as a turn inward, as though that is the final destination, is to completely misunderstand Christianity and the conversion process itself. Instead, conversion to Christianity should be viewed as a post-relational ontological (re)turn to relations. By combining these theories, Hiebert's and Holbraad and Pedersons's, I hope to show that there is movement and transformation long before the one-time event of entry into the faith that many anthropologists seem to view through a bounded set understanding of the process. Likewise, there is movement and transformation after this one-time event as well. Understanding the movement of conversion is significant for understanding Christianity as a whole.

\section{The Problem with Applying Bounded-Set Theory to Conversions}

The first challenge that must be addressed in researching this question is how we define groups. Hiebert suggests that we can view groups such as organized religion as bounded or centered sets (1978). Bounded sets identify who is in and who is out, separating members from nonmembers of the group. Centered sets place the goal at the center (in the case of Christian conversion, the center is a relationship with Jesus) and understand that people are either moving toward or away from the center. Whether Christianity is or should be a bounded set is ultimately a theological question. For now, however, I am challenging the way anthropologists view Christian conversion as though it happens in a single moment through a one-time event of entry into the faith, thus defining Christianity as a bounded set.

In anthropology, we divide our subject matter into "distinct cases: each society with its characteristic culture, conceived as an integrated and bounded system, set off against equally bounded systems," says Wolf (2010:4). In Christianity, we like to think of people as saved or not saved, believers or unbelievers, members or nonmembers of the church. In reality, people live a dynamic experience wherein each moment, emotion and circumstance through years of living can culminate in a gradual transformation into something brand new. Individuals may not be entirely aware that the challenges and frustrations that happened in one circumstance could be what motivated them to seek out a new circumstance. This is true of Ajay and his wife Vardaniya. 'When I asked them to tell me how they converted to Christianity, Ajay began by saying,
"So before I was a Christian, I had a lot of stomach problems and diarrhea and I couldn't keep my food down. I was getting up many times at night and during the day. I tried all types of medicine, all kinds of religious worship [shamanistic rituals] and Hindu worship. So I went to many witch doctors and all the witch doctors used to say that somebody had cursed me. So I went to the field to find that matta in like a Hindu garden and then she comes into your life and she speaks."

I interrupted and asked, "What is a matta?" He said, "Matta is like when you worship an idol and the spirit comes in your life and that is called matta and I went to go look after the matta. I went to go see that person and she said that, 'People have been doing bad things to you and you are not going to live long and if you live long it will be 3 years and not more than that.' She said, 'I can give this water for you to drink and you can feel better but I cannot do anything more.' When she said that, 'You are not going to live long,' I was so worried about my wife and if I die how will she survive? and I was worried.

"After this happened a neighbor-she is not Christian-started to tell about a man named Vihaan and how he got healed. They were saying how he got healed by Jesus, so they started to share that with me and I was interested in hearing that. Then later, I went to meet Vihaan and his family and asked him how he got healed. And I was so interested and I was asking, 'Can God heal me also?' They answered, 'If you believe and you trust in God he can heal, but you need to come church.' So, I told them, 'God can heal!' I had lost my hope completely when I was sick. And I thought that I was already dead. I was not going to live more, I was going to die. And I always talked like that I was not going to live anymore. I talked like that. When I believed [in Jesus] my life came back and I had hope. Because of that, I changed. It changed my faith."

I asked him, "When you prayed to Hindu gods did they ever answer your prayers?" He answered, "No, we never get an answer, but sometimes when we pray, like you feel a little bit better, but not totally healed. And sometimes we call the witchdoctor and they would worship and kill a sacrifice and after a few days, like one week, it feels kind of better. But after one week it comes right back." Then I clarified by asking, "Both with Hindu gods and with the witchdoctors there is a little bit of change but it doesn't last? If you never saw answers to prayers why did you keep believing in the Hindu gods or the witchdoctor for so long?"

He said, "We just hoped that maybe it would be better sometimes. When I was a Hindu, I really

\footnotetext{
${ }^{1}$ All names of people I interviewed are pseudonyms to protect their identity.
} 
trusted and believed those gods and goddesses and I used to go a lot to the temples. Especially because we don't have our own child, and because of that I really wanted to have one. So, all the time I was going to the temple and trusting and believing and praying for it. But it didn't happen and I was very upset. My wife and mother would decorate our house for the worship to the idols but during that time I would get so mad and I would just throw everything, because it was not working. I felt that I really trust these gods and goddesses but they are not giving me anything and I am still suffering and having a hard time so I need to go, I need to find the truth.”

Eventually, Ajay and his wife found 'the truth' in a relationship with Jesus Christ. Through their journey, each moment of heartache and frustration with both the Hindu worship system and the shamanistic worship rituals produced mini-ontological shifts away from those belief systems. The cumulating effect of all of those mini-ontological shifts was a seeming one-time event of entry into Christianity. As with Ajay and Vardaniya, most people do not simply decide to change religions at one specific moment, but rather go through a series of situations that have led them to the point where they more closely identify with the new faith than their old belief system.

Following Hiebert's model, if we apply centered-set theory to Ajay's story, we can see that long before he went through the process of conversion to Christianity, he was on a trajectory in which his worldview was crumbling. He had "really believed in those gods and goddesses," but they continued to disappoint and frustrate him. With each devastation, the tight grip he had on his worldview was loosening. For Ajay, there was a central goal of finding "truth" and a truth which provided tangible, lasting results from prayer. If anthropologists are using a bounded set when discussing Christian conversion, there is a great potential that they would miss seeing the people who are on the journey of becoming Christians. By demanding that conversion be viewed as a cross-over between bounded systems, anthropologists are negating the journey towards Christianity that happens in advance of the event.

When we view humanity as a whole instead of dividing people into groups, we can begin to see our common human experience as a movement or journey toward a goal. In order to apply centered-set theory to the anthropology of religion, then, we must be willing to remove all of the labels that we have applied to categorize groups. Then we must ask ourselves, what is the goal of all religious people? I suggest that a common goal of all religious people is salvation/redemption by which they attain a better life both now and after death. In pursuit of this goal, then, they may convert to a new religion.

By analyzing conversion from one religion to another using the centered set model, the question changes from "when and how did the change occur" to "what is the nature of the journey involved?" In his ethnography on the conversion of the Tamang in Nepal, Fricke wrote,

Like Williams James, we like our conversions neat. If they come with falling off a horse and being blinded, all the better. As Gary Wills writes, "The Stories of Paul and Augustine have led to a belief that, 'real' conversion is sudden, affected by the incursion of an outside force, and emotionally wrenching. But most of us know it to be a messier process-or at least that the processes are various.” (2008:47).

All converts go through a metamorphosis that involves relational, existential, and cosmological changes along with other transitions. Thus, in the case of conversion to Christianity, we can view the change as a process of moving toward a relationship with Christ in order to find salvation, and we can describe it as a transformation instead of as a rupture.

In anthropology, conversion has been framed as a disjunctive process in which the normal linear trajectory of life is ruptured and a new trajectory is established. Trajectories of life can include relationships, belief systems, and worldviews. This disjunctive formula is applied most heavily in ethnographies of tribal cultures, where people tend to be highly relational due to kinship structures. Anthropologists studying Christian conversion have looked at these situations and divided groups into two camps, Christian and non-Christian, partly because of their interest in contrasting traditional and modern cultures. Informants also make sharp distinctions in their narratives of their lives before and after salvation (Gibson 2017b: v). But more careful and extensive ethnography reveals that such dramatic demarcations are often the product of more gradual progressions of changing belief systems. Conversion is about transforming your thoughts and actions and is often a long, arduous ordeal. What we gain from understanding set theory is the ability to analyze people in process and on a journey toward converting to Christianity.

\section{The Post-Relational Ontological Turn}

When we view conversion as a transformative process, we understand that all stages (before, during and after) are equally important when analyzing the conversion experience. There is a debate in anthropology over the degree to which conversion produces a rupture with culture and with social 
relations. Some in the anthropology of Christianity have suggested that conversion to Christianity entails a turn away from an ontology in which social relationships figure prominently in the construction of the self to one in which there is a turn inward (Robbins 2004; Keane 2007). But I would like to suggest that the rupture with relationships in conversion to Christianity is never complete. In fact, these same relationships are not only transformed but often restored subsequent to the conversion.

In, The Ontological Turn: An Anthropological Exposition, Holbraad and Pedersen (2017) point out that most anthropologists studying Christian conversion believe that in relationship-based cultures, when people choose to convert to Christianity, they are turning from an ontology of prioritizing relationships to a selforiented ontology. In the case of Melanesian and Amazonian conversions, Robbins, Schieffelin and Vilaca (2014:586) believe that converts become increasingly less socially engaged and more introspective. Holbraad and Pedersen quote them as saying, "This focus on the inner self is further linked to a decreased (though never wholly absent) moral interest in the state of social relations in favor of one placed on the inner self, particularly as it is known by and related to God" (2017:251). Holbraad and Pederson believe that this shift in ontology should be viewed as a part of a transformative process of the whole person. "Conversion should be understood more literally as the transmutation of one form into another form, like when a convector turns steam into hot water (2017:260)." Perhaps a more fitting analogy is like a caterpillar (nonbutterfly) morphing into a butterfly-the convert goes through a process that takes him/her from being a nonChristian to being a Christian. The transformation opens up 'the great indoors,' a place where existential, cosmological, and epistemological questions and answers are developed within the self. Holbraad and Pedersen go on to explain, "This introspection happens at the expense of prior social relationships; not necessarily in the sense that relationships to other people ceases to exist or matter, but because such exterior relations now seem to become inflected and encompassed by an interior relation to God" (2017:259). They continue by saying, "For is it not in this 'great indoors' of Christian introspection that all relations cut-off in conversion may be said to re-emerge, only now in what is a non-social, introvert form?" (2017:260). Yet, this re-emergence of relationships, I would counter is actually a return to a relational status that is demanded in Christian doctrine as I will describe below.

As I said earlier, some of the confusion over this issue comes from the converts themselves. Robbins says that, "Converts themselves experience, or talk about the experience, of conversion, namely as a radical, discontinuous, and irreversible rupture from one religious, cultural and moral order to another" (2017:247). Commonly, this shift from one religious order to another does create conflict for the convert in social relations. However, while relationships may initially be damaged they are usually restored. For instance, one of my interlocutors Aditya, tells this story:

"So, most of the people in Nepal, they convert to Jesus because they are sick, and God healed them, so then they come to the Lord. But I was not sick then, but I was looking for the true God. I went to the church to listen to the music because I liked it and slowly I understood that Jesus is the true God, so I accepted Jesus. I was a very strong Hindu. My father, was a kind of a rabbi or a teacher . . . a Hindu priest. According to our customs, the first-born son has to follow in the father's job. So, I was supposed to follow in my father's steps, become a Hindu priest and do magic and witch doctor things. But when I became a Christian, my father kicked me out of the house and I moved into Vivaan's house."

I asked if conversion was a difficult decision or if he regretted it, and he said, "It was not the easiest. It was really hard, not easy. We were young, but I was very, very committed." "Do you talk to your father now?," I asked. "Now my father is saved so there is no problem now, but in the beginning, it was. After twelve years my father became a Christian.” I asked, "Is the rest of your family saved?" "One day! One uncle and one sister are not saved but everyone else is saved. When I was young my mom passed away, so I only had a father.”

It took twelve years for Aditya's father to convert to Christianity and for that relationship to be restored. At any point before the father's conversion, if I had talked to Aditya, he could have described a situation that looked hopeless for restoration. Yet over the long term, restoration was not only possible but occurred in this case, as in many others that I encountered.

In general, anthropologists of Christianity have had a tendency to exaggerate the individualism promoted by Christian conversion. Michael Scott critiques the 'rupture model' by saying that, some scholars "tend to construct only one model of personhood . . . and they posit this model as definitive, either of Christianity as a whole or, more narrowly, of the particular kinds of Christianity they study." Yet, Scott goes on to say, ”I would not deny that there are Christians who think and act according to various versions of quasi-atomistic, vertically oriented model of Christian personhood. I would argue, however, that such a model is not alone in the history of Christianity; others have always coexisted, either in combination or conflict with it" (cited in Holbraad and Pederson 2017:250). The wide range of 
conceptions of personhood in Christianity, then, suggest that Robbins and others are overgeneralizing the turn toward individualism in Christian conversion.

Holbraad and Pedersen ask,

What happens to all the social and spiritual connections severed in the processes of conversionwhere, as it were, do all the cut-off relationships go? While processes of Christian conversion have often been understood by anthropologists to involve a reduction of relationality (sociality), it might, we suggest, be more analytically interesting and potentially more faithful to the ethnography to think of conversion as a relational transformation (2017:256).

So, the convert is not only undergoing a personal transformation in their relationship to society, but the very nature of their understanding of relationships has evolved as well. Holbraad and Pedersen go on to say that, "Christian conversion . . . may thus be theorized as an enfolding or involution of human and non-human relations that keeps relational complexity intact but displaces this complexity from an exterior realm we tend to think of as 'social' to an interior domain we here shall call 'existential"' (2017:257). When the entire nature of relationships are transformed, that can include the prioritization, the mechanics, and even the affective outcomes of said relationships.

Nonetheless, there is some truth to the notion of the "great indoors" that is opened up in Christian conversion. Holbraad and Pedersen suggest,

Perhaps, when someone becomes a Christian, her [or his] 'self' does not just become more singular, bounded and discrete, as received wisdom has it. Rather, what happens might also be theorized as relational 'involution,' where a multitude of exterior agents within the surroundings is substituted by a multitude of interior affects (belief, doubt, love) appearing on the inside of a new, correspondingly inflated self. (2017:260).

This 'great indoors' where all this introspection is taking place, is the breeding ground where the teleology (meaning/design and purpose) of the Christian narrative can grow and blossom, producing personal transformation. For it is not only belief, doubt and love that take root in the 'great indoors' but a plethora of phenomenological experiences including faith, hope, and peace. The purpose or design of the story of Christ is to bring freedom to people in their "great indoors" by transforming it from a place where chaos, fear, and hopelessness reign to a place where faith, hope and love reign in relationship with Christ. The ontological shift from an exteriorly motivated person to an interiorly motivated person has created an avenue for that Christian narrative to be established. Now it can begin to shape not only the convert's existential reality but the whole set of their relationships as well.

Combining Hiebert's centered-set theory with the notion of the relational transformation from Holbraad and Pedersen, we can witness the recurring language of movement and motion. By applying the post-relational ontological turn theory of Holbraad and Pedersen in conjunction with the centered-set theory of Hiebert, we can see that these theories will give us a deeper and richer account of what is going on in conversion. They provide a nuanced approach to studying the motivations and effects of conversion that is both anthropologically sound and reflective of informants' testimonies.

The work of Holbraad and Pedersen in defining 'the great indoors' is incredibly important, however I believe it is short-sighted. During conversion to Christianity, there is an ontological turn from an exterior driven relational culture to an introverted and introspective ontology. However, the conversion process does not stop there. Converts certainly go through a process in which they reprioritize relationships and self. But Christianity demands that the transformation process must continue to a place where relations are once again highly valued. Where Holbraad and Pedersen feel confident in stating that there is a post-relational ontological turn, I suggest that we must take that theory one step further and define conversion as a post-relational ontological (re)turn to relationships.

\section{The Post-Relational Ontological (Re)turn to Relations}

It is incredibly important to know the nature and character of God in order to understand why someone would desire to convert away from or to a specific religion. As secular anthropologists have attempted to understand what would motivate people to convert to Christianity, they have missed much because they are approaching it from an outside stance. By exploring Christian theology, I will show that Holbraad and Pedersen's theory of a post-relational ontological turn to 'the great indoors' stops short. The short-sightedness of their theory could be from ignorance of Christian theology or it could be from the typical disdain that anthropology has towards integrating theology into anthropological theory. Nevertheless, even from an anthropological viewpoint a more careful look into ethnographies would surely testify to the fact that new converts do not continue to live a life that is selfpreferential, and that true Christendom requires that love be expressed towards others. Therefore, in this section, I will highlight the theological background that 
proves that Christianity has an inherent call for converts to give love to others and not to remain self-focused.

The heartbeat of Christianity is around a central theme of love, and in order to love you must have relationships. This love originates in the Triune God: three distinct persons and roles, all comprised in one being. Their very nature is described as love in $1 \mathrm{John}$ 4:8, "Whoever does not love does not know God, because God is love" (NIV). Theologians have speculated that the initial desire for creation was birthed from a place of sharing love within the Trinity and wanting to extend that love to a created being. "God was complete in Himself, not needing a created object to which He could express His love. For this reason, God's act of creation can be seen as an act of perfect, selfless love, and not an act to fulfill a need. It was out of the perfect love within Himself that God created and loves His creation" (Stewart, 2017:12). Throughout the Old Testament God refers to Israel as a bride, a metaphor for a beloved one. The greatest example of love in the canon is embodied, literally, in the man Christ Jesus. His incarnation, life, death and resurrection tell a love story. Milbank writes, “...No other picture, save of incarnation in a joyful and suffering life in time, gives quite such an acute notion of divine love, and involvement in our destiny" (2006:386). From the very beginning, before the world was even created and following through until the age of the church the mandate and motivation has been love. There is no other narrative quite like the story of Christianity for placing love at the center of the ontology it represents.

In Theology and Social Theory, Milbank explores the history of thought that has laid the foundations for the social sciences today. In epic form, he debates the claim of secularism to be the true ontology on which social life is based, and contrasts that "ontology of violence" with the Christian "ontology of peace," which identifies loving and harmonious relationships as the actual nature of reality as created by God. He offers up Christian theology as the best narrative to describe the human condition. And, he reminds us that Jesus' own purpose was to form a community of loving relationships:

Jesus's mission is seen as inseparable from his preaching of the Kingdom, and inauguration of a new sort of community, the Church. Salvation is available to us after Christ, because we can be incorporated into the community which he founded, and the response of the community to Christ is made possible by the response to the divine Son of the divine Spirit, from whom it receives the love that flows between Son and Father . . . Hence the metanarrative is not just the story of Jesus, it is the continuing story of the Church, already realized in a finally exemplary way by Christ, yet still to be realized universally, in harmony with Christ, and yet differently, by all generations of Christians. (Milbank 2006:389)

The value of community is fully entrenched in Christine doctrine beginning with the Triune God and is fully expressed through the church, as they fulfill God's commandments through the Great Co-Mission (Mt. 28).

In Matthew 22, Jesus was tested by the Pharisees (the experts in the Jewish law) and was asked which was the greatest of all the laws. While God had given just ten original commandments, the Jewish leaders of the time had created many additional laws. The initial ten laws had multiplied into 613 laws of which the Pharisees were experts. Thus, when the Pharisees approached Jesus, they were setting a trap for him by forcing him to choose between laws. Jesus answered their question by selecting the following: "'Love the Lord your God with all your heart and with all your soul and with all your mind.' This is the first and greatest commandment. And the second is like it: 'Love your neighbor as yourself.' All the law and the prophets hang on these two commandments." (Matt 22:37-40, NIV). In this answer, Jesus acknowledged that from the very beginning the heart of the Triune God has desired that humanity would respond in love back to the Creator as well as to give that love to the world around them. The missio Dei (mission of God) began, then, with the Trinity inviting creation to know real love and being given the opportunity to share it with others. This is what God's desire was throughout the old covenant, and it was confirmed when Jesus came to show the world what that love looks like in practice. It is possible to live a life that is wholly devoted to God in lovesick adoration and to love your neighbor in a self-sacrificial manner as well. This is the Christian narrative, whether or not the church lives up to it as it should.

Conversion stories reveal the heartbeat behind the missio Dei. Ultimately people who convert to Christianity are responding to the nature and character of God, who is completely different from what they have understood in their previous religious lives. As people encounter the God made manifest in the Father, Son and Holy Spirit, people are exposed to the realities of love both in the man Christ Jesus but also in the mission of Christianity. The opportunity to receive love from God entices people to give love away to friends and family who are hurting as well (1 John 4:19).

Having looked briefly at the theology of the Christian doctrine of love, we can now see that in the conversion process there is, as Holbraad and Pedersen mention, first a turn away from a relational ontology to an ontology that preferences the formation of the self, but then there is another turn back to relationality. It is 
necessary for every person to make a choice for their own personal faith journey in Christianity and this entails making a decision independently of one's family and friends. But then the Christian ontology of God as Trinity and its ethic of love step in to cause converts to reestablish relations in order to offer them the love of God.

Once again, as new converts go through the transformative process of becoming Christians, they will eventually make a choice to place their faith in Christ which involves an ontological turn away from groupthink to an ontology based in the interior life and responsibility of the self. But, the longer that converts engage with Christian culture, the more that they will come to understand that the Kingdom of God is about loving other people, including family. Thus, they will make a second ontological turn, this time back to relationality. Their thinking will have been transformed in the process, from a passive acceptance of their group's injunctions to a more carefully considered understanding of the importance and purpose relationships. This new relationality will allow these Christian converts to fully represent the missio Dei in an altruistic manner.

From this discussion we can see that in order to fully understand the process of conversion from an ethnographic point of view, anthropologists must be willing to approach conversion from an emic standpoint and understand the theological teachings of Christianity. By using an integrative approach to studying conversion, incorporating both anthropological and theological insights, we will be able to present a more substantial and cohesive argument for what happens during conversion.

\section{Conclusion}

The biggest challenge for anthropologists lies in our starting point which has created a bounded/binary system for categorizing groups of people. When anthropologists approach the anthropology of religion by segregating people into groups based on their current affiliation with a particular religion, we are negating the fact that life is an ongoing transformative process. Instead, if anthropologists would approach conversion as a centered-set and begin to view all of humanity as though they are on a journey toward a relationship with the divine for purposes of salvation, then we would understand conversion in a completely different way. Centered-sets allow us to see people who are in the process of being transformed into Christians even though they have not yet gone through the conversion event. It will also allow us to see that even after the event has occurred, it can still take a long time before a person actually behaves like a Christian.

Once we have properly understood set theory and its importance to understanding conversion, then it is critical for anthropologists to delve deeper into understanding the transformative nature of conversion by specifically looking at Holbraad and Pedersen's postrelational ontological turn theory. While I fully agree that in the process of conversion people are turning from an ontology of relationality to an ontology which focuses on the interior life of the self, or 'the great indoors,' I do not believe that this is where conversion ends. Instead, I believe that real Christianity beckons believers (old and new) to live a life of love towards those around them. The metaphors that Christians live by $^{2}$ are all based heavily in relationality as we identify ourselves as a bride, as sons, as daughters, and other such relational terms. Thus, as anthropologists we must approach understanding conversion through an integrative process consulting Christian theology along with anthropological theories.

Conversion is a life altering process whether you are in Nevada or in Nepal. Whether conversion is towards Christianity or away from it, the process that people go through to convert is profoundly transformative. Long before the conversion event takes place, and long after as well, individuals must make daily choices to rewire the way that they see the world so that their life is congruent with the teachings of their faith. Conversion is a renewal process that creates a brand new person. Everything that defined the old individual must change as well. Relationships, worldviews, and practical daily decisions will go through a refining process until they mirror the doctrine that guides their life. Thus, in the long run, rather than rupture, conversion to Christianity produces love, hope, peace and joy that are spread from one person to another through relationships.

\section{Bibliography}

Fricke, Tom. 2008. "Tamang Conversions: Culture, Politics and The Christian Conversion Narrative in Nepal." Contributions to Nepalese Studies (CNAS/TU) $35(1): 35-62$.

Gibson, Ian. 2017a. "Pentecostal Peacefulness: Virtue Ethics and the Reception of Theology in Nepal." Journal of the Royal Anthropological Institute 23:765-782.

— - 2017b. Suffering and Hope: Christianity and Ethics among the Newars of Bhaktapur. Kathmandu: Ekta Books Pvt Ltd.

Gordon-Conwell Theological Seminary. 2013. Christianity in its Global Context, 1970-2020: Society, Religion and Mission. South Hamilton, MA: Center for the Study of Global Christianity.

Hiebert, Paul. 1973. "Conversion, Culture, and Cognitive

\footnotetext{
An homage to "Metaphors We Live By" by George Lakoff and Mark Johnson (1980).
} 
Categories." Gospel and Context 1(4): 24-29.

. 2008. Transforming Worldviews: An Anthropological Understanding of How People Change. Ada, MI: Baker Academic.

Holbraad, Martin and Morten Axel Pedersen. 2017. The Ontological Turn: An Anthropological Exposition. Cambridge: Cambridge University Press.

Lakoff, George and Mark Johnson. 1980. Metaphors We Live By. Chicago: The University of Chicago Press.

Keane, Webb. 2007. Christian Moderns: Freedom and Fetish in the Mission Encounter. Berkeley, CA: University of California Press.

Meneses, Eloise, Lindy Backues, David Bronkema, Eric Flett, and Benjamin L. Hartley. 2014. "Engaging the Religiously Committed Other: Anthropologists and Theologians in Dialogue." Current Anthropology $55(1): 82-104$.

Milbank, John. 2016. Theology and Social Theory: Beyond Secular Reason, 2nd ed. Malden, MA: Blackwell Publishing.

Robbins, Joel. 2004. Becoming Sinners: Christianity and Moral Torment in a Papua New Guinea Society. Berkeley: University of California Press.

Robbins, Joel, Bambi B. Schieffelin and Aparecida Vilaca. 2014. "Evangelical Conversion and the Transformation of the Self in Amazonia and Melanesia: Christianity, and the Revival of anthropological comparison."

Comparative Studies in Society and History 56(3):55990.

Stewart, Sarah. 2017. "Yahweh and Allah-the Essential Differences: Why Christians and Muslims Do Not Worship the Same God and Why it Matters.” Liberty University.

Wolf, Eric R. 2010. Europe And the People Without History. Berkeley: University of California Press.

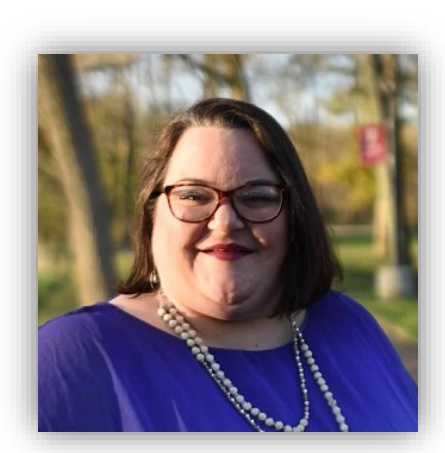

Jill L. Hurley was born and raised in Texas but completed her undergraduate work at Eastern New Mexico University in Portales, NM, with bachelor's degrees in Religion and in Anthropology. Her undergraduate thesis was on race and racism at ENMU, a Hispanic serving institution. Jill is particularly interested in the processes of constructing and deconstructing culture, and more specifically where and how faith intersects those processes. She recently graduated with a master's degree in Theological and Cultural Anthropology from Eastern University in St. Davids, PA. Her most recent fieldwork was completed in Nepal in 2017, where she focused on the Anthropology of Christianity, specifically looking at conversion from Hinduism to Christianity. Jill hopes to bring her love for the world and faith, both in their beautiful complexity and diversity, to students in the near future.

Author email: jill.hurlev@eastern.edu 